\title{
OPEN BUSINESS MODELS AND VENTURE CAPITAL FINANCE
}

Word count: 10,402 (main body plus reference list)

\begin{abstract}
We investigate the differences in venture capital (VC) governance of investee firms with Open Business Models (OBMs), specifically Open Source Software (OSS), versus closed business models. Due to OSS's pronounced complexity and uncertainty, we conjecture that VC-backed OSS firms are more frequently staged and syndicated. We present robust empirical evidence from the US that OSS ventures have more financing rounds and are more likely to be syndicated, and mixed evidence that OSS ventures have a larger number of syndicated investors.
\end{abstract}

(Word count: 80)

JEL classification: G24, L17, L26, O31

Keywords: Open Business Model, Entrepreneurial Venture, Open Source Software, Staging, Syndication, Venture Capital

Revised paper submitted to the Special Section of Industrial and Corporate Change on Open Innovation. 


\section{INTRODUCTION}

The business model of an entrepreneurial venture affects the ways in which entrepreneurs and their investors create and capture value from their underlining knowledge and technology (Teece, 2010; see also Amit and Zott 2001, Zott and Amit 2007, George and Bock 2011). The venture capital (VC) literature has so far implicitly assumed that venture capitalists (VCs) usually finance technologybased ventures with closed business models, i.e., ventures that create value from the knowledge and technologies that they develop (mainly) using internal resources and that they (mainly) exploit them within their boundaries (Sandulli and Chesbrough 2009). The academic focus of closed business models does not fit with the growing popularity of open innovation. Increasing competition and cost of product development together with the increasing diffusion of the open innovation approach (Chesbrough, 2003) have recently led many ventures to adopt open business models (OBMs). In OBMs, the main source of value generation is leveraging of external sources of knowledge and technologies and/or the sharing of internally developed knowledge and technologies they develop with third parties (Chesbrough 2006). Accordingly, the system of activities undertaken by ventures extends outside their boundaries (Casadesus-Masanell and Llanes 2011), increasing the complexity of the business model. This has implications for the viability and sustainability of ventures' revenue generation models (West 2007, Casadesus-Masanell and Llanes 2011), which become more uncertain. Thus, at first glance, one would expect that VCs perceive ventures adopting OBMs as risky and difficult to manage. While evidence exists that ventures with OBMs do receive VC financing (Aslett 2009), there is no theory or evidence on the structure and governance of the VC-entrepreneur relationship for OBMs.

This paper addresses the following research question: "In what ways does the governance of VC financing of ventures with OBMs differ from that of ventures with closed business models?" We argue that the complexity of the systems of activities and the uncertainty of the revenue generation model that characterize ventures with OBMs requires intensive monitoring by VCs via staging; i.e., the stepwise provision of several rounds of VC finance, rather than making an upfront investment of all required capital (Sahlman 1990). Likewise, we expect that VC financing of ventures with OBMs requires higher levels of syndication, namely, the joint investment of two or more VC investors in the 
same entrepreneurial venture (Lerner, 1994; Tian, 2012). Indeed, in the complex and uncertain context of OBMs, syndication facilitates pre-investment due diligence as well as post-investment value creation.

To the best of our knowledge, no other study has examined how the adoption of OBMs by entrepreneurial ventures influences the investments they received from VCs. Our study advances the literature in two main directions. First, it advances current knowledge on OBMs. Scholars have mainly focused attention on the consequences of OBMs on firm performance, and prior literature has shown that OBMs may help firms in creating value through increased innovative performance (Laursen and Salter 2006), reduced costs (Lakhani and von Hippel 2003), and improved product quality (Chesbrough 2003). However, the link between OBMs and firms' financing has not been adequately investigated. Alexy and George (2013) provide evidence that adopting OBMs affects the value of public firms and have called for further research on this topic. We complement their results by focusing on privately held ventures with OBMs and analyzing the peculiarities of the governance of the VC financing that these firms attract. Second, we contribute to the literature on VC financing of entrepreneurial ventures. Prior work has offered some qualitative evidence that VCs attach importance to a venture's business model (Kaplan and Stromberg 2004). However, empirical studies have largely treated entrepreneurial ventures as homogenous entities with respect to their business models. In this study, we show that this is not the case: the complexity and uncertainty associated with OBMs affect the governance of investments that ventures adopting these business models receive from VCs.

Our study has also practical relevance. The adoption of OBMs is more and more diffused and increases the information asymmetries that prevent ventures from accessing traditional sources of capital (Hall and Lerner 2012). As VCs are particularly able to cope with information asymmetries, VC financing seems the right form of financing for ventures with OBMs. Evidence from the real-word supports this conjecture: VCs investments in ventures with OBMs are fairly widespread (Aslett 2009, 2010). However, the uncertainty and complexity of ventures with OBMs require ad hoc governance mechanisms for these investments. This study sheds light on these mechanisms and thus offers interesting insights to both entrepreneurs who are searching for VCs and VCs who want to leverage the growth potential of ventures with OBMs (see the concluding section for an extensive discussion of 
the practical implications of our results).

We also recognize that OBMs may assume diverse forms (see, e.g., Chesbrough 2007). Therefore, we develop our theoretical arguments in the context of one prominent category of OBMs: the business models that ventures build around Open Source Software (OSS) developed by the Open Source community; i.e., the OSS-based business model (Chesbrough and Appleyard 2007). A venture can adopt an OSS-based business model and capture value from OSS in several ways. These include selling support services on OSS programs, engaging in versioning by providing advanced versions of OSS programs as value added-offerings, integrating OSS with proprietary hardware, and providing proprietary complements to OSS programs (Chesbrough 2006). All these ways of profiting from OSS are OBMs. Indeed, they entail leveraging software and knowledge created by the OSS community outside firms' boundaries and, in some cases, the sharing of internally developed software and knowledge with the OSS community (Henkel, 2009).

To test our hypotheses, we use a sample of 500 VC-backed software entrepreneurial ventures obtained from SDC Platinum (VentureXpert), which received 2,018 rounds of investments. Of these entrepreneurial ventures, 119 adopted an OSS-based business model (hereafter 'OSS ventures'), while the remaining ventures adopted a proprietary software business model (hereafter 'proprietary software ventures'). In line with our expectations, results indicate that VC investments in OSS ventures are more frequently staged and more likely to be syndicated. In order to allay concerns about alternative explanations and unobserved heterogeneity, we use an extensive list of controls and alternative estimation techniques, including instrumental variables and propensity score matching.

This paper is organized as follows. In the next section, we provide the theoretical background and develop the research hypotheses. Then, we describe the data and methodologies used in the analysis and present our results. In the concluding section, we discuss the main contributions of the paper, highlight its limitations, outline directions for further research, and discuss practical implications.

\section{THEORY AND HYPOTHESES}




\section{THE Challenges OF THE OSS-BASED BUSINESS MODEL}

In line with previous studies, we contrast an OSS-based business model with a proprietary software business model based on two key dimensions: the system of activities and the revenue generation mechanism (Amit and Zott 2001, Zott et al. 2011). ${ }^{1}$

Entrepreneurial ventures adopting a proprietary software business model rely on intellectual property rights (IPRs) combined with other appropriability mechanisms (e.g. lead-time) to both protect their internally developed software from imitation and to capture the value generated from the software by licensing the machine code. In other words, the revenue generation model of proprietary software ventures is based on exploiting a (temporary) monopoly rent generated by their proprietary technology. Regardless of whether proprietary software ventures collaborate with third parties (e.g., universities or other firms), their system of activities is centered primarily on their internal R\&D activities, and value creation largely depends on the human capital of their employees who work as software programmers.

Entrepreneurial ventures adopting an OSS-based business model leverage the OSS community for business purposes (Bonaccorsi et al. 2006; Chesbrough and Appleyard 2007). They may sell support services on OSS programs, provide advanced versions of OSS programs as value addedofferings, integrate OSS with proprietary hardware, and sell proprietary complements to OSS programs (Chesbrough, 2013). Moreover, ventures with an OSS-based business model can make available internal developed software under an OSS license to increase its adoption and allow customization by users (Capra et al. 2011). Often, for running their business, OSS ventures establish close collaborations with OSS developers, thus obtaining access to competencies that they do not possess internally (Dahlander and Magnusson 2005; Piva et al. 2012). In sum, the system of activities of OSS ventures goes beyond internal development of software and knowledge.

In most cases, the revenue generation mechanisms of OSS ventures belong to two distinct, although conceptually similar, categories: versioning and selling of complementary offerings. Also proprietary software ventures might also resort to these categories of revenue generation mechanisms. However, in the OSS context, they do not base their model on the exploitation of IPRs, which, in the OSS realm, are designed to favor, and not to prevent, the access by third parties (Gruber and Henkel 
2006).

OSS ventures that resort to versioning (Shapiro and Varian 1998) give away a basic version of OSS software for free and sell a premium version of that software, which includes proprietary advanced features and targets less price-sensitive customers (Goldman \& Gabriel 2005, Perr et al. 2010). OSS ventures relying on versioning take advantage of the diffusion of the basic OSS version, which generates direct and indirect network externalities (Katz and Shapiro 1985, Gandal 1995). First, users can adopt and try out the OSS version at low cost, and this may induce them to upgrade to the proprietary version ${ }^{2}$. Second, the frequency of testing and the quantity of feedback available to OSS developers about the basic OSS version increases with the number of its users, thus improving the quality of both basic and premium versions. Third, with an increasing number of users of the basic OSS version, it becomes possible for customers who buy the premium version to exchange files and knowledge with a larger crowd. Fourth, the more widespread the basic version is, the greater the incentives for OSS developers to produce applications compatible with the basic version. To the extent that these applications are also compatible with the premium version, they increase its value.

A second revenue-generating mechanism includes selling solutions that are complementary to one (or more) OSS solution(s) developed by the OSS community or even that a venture has developed on its $\mathrm{own}^{3}$. A prominent example is Red Hat, which monetizes on providing support and updates for the Linux operating system, whose code is freely available on the Internet. Other ventures use the Linux operating system in combination with proprietary hardware devices like mobile phones and machine controls (Gruber and Henkel 2006). The fact that OSS solutions are free of charge increases demand for complementary products or services. The direct and indirect network externalities at work in the software realm (Katz and Shapiro 1985) magnify this effect. This revenue generation mechanism is viable only if complementary products and services are sold in an imperfectly competitive market (Fosfuri et al. 2008). In such markets, the unique assets controlled by an OSS venture can hardly be replicated by competitors and, thus, confer an advantage to the focal venture (Teece 1986). Examples of these assets include ownership of the hardware technology or commercial assets, such as a reputed brand or an effective sales force.

Starting from the above premises, we articulate the core argument of this paper. The system of 
activities and the revenue generation mechanism of OSS ventures are more complex and, thus, more difficult to manage than those of proprietary software ventures. Accordingly, the returns generated by an OSS-based business model are more uncertain than those generated by a proprietary software business model and depend much more on the firm's managerial capabilities.

The complexity and consequent managerial challenges of OSS ventures' systems of activities have their roots in the nature of the OSS community (see Colombo et al. (2013) for an extensive discussion). First, the OSS community is potentially open to everybody. Therefore, OSS ventures do not have full control over the OSS development process and the quality of its output (O'Mahony and Bechky 2008, Dahlander \& Magnusson 2008). While some OSS developers are eager to signal their talent by developing high-quality software with the aim of obtaining a better job, others write OSS code just for fun and are less committed to quality (von Krogh et al. 2012, Lerner and Tirole 2002). Second, no formal contract rules the software development activities within OSS projects (Dahlander and Magnusson 2005). As stated by O’Mahony (2003), OSS developers are not the employees of the OSS projects to which they contribute. Consequently, nothing assures either their continuous commitment to the OSS projects that OSS ventures leverage for commercial purposes or the alignment of their objectives with those of OSS ventures. Project discontinuities, departure from initial specifications, delays in software delivery, or delivery of low quality software are risks that OSS ventures face in OSS projects (O'Mahony and Ferraro 2007, Dahlander \& Magnusson 2008). OSS ventures can limit these risks by directly collaborating with OSS developers. For instance, these firms can pay their employees to contribute to OSS projects or sponsor the most talented developers in the OSS community (Dahlander and Wallin 2006, Henkel 2009). These moves give OSS ventures visibility within OSS projects and enable them to influence their future direction ${ }^{4}$ (O'Mahony and Bechky 2008). However, collaborations with OSS developers are far from simple; to take part effectively in the OSS community, OSS ventures must learn and respect unwritten norms and values.

The aforementioned challenges of OSS ventures' systems of activities threaten the viability and sustainability of their revenue generation mechanisms. If an OSS venture relies on versioning, unexpected changes in the rate and direction of the software development process within OSS projects may reduce the quality of the OSS basic version or generate delays in the delivery of updates, thus 
slowing down its diffusion. This reduces the benefits, in terms of direct and indirect network externalities, for the premium version and consequently its demand. Versioning may also become increasingly difficult, if OSS developers improve the quality of the basic version up to the point that the premium version has no additional value for paying customers, who will then self-select in the basic version. Similar problems may also arise for OSS ventures whose revenue generation mechanism revolves around the sale of complementary products and services. Deterioration of the quality of OSS solutions may reduce the value of OSS ventures' complementary offerings or force OSS ventures to incur unexpected costs, such as restoring compatibility between their products and the OSS solutions.

\section{RESEARCH HYPOTHESES}

In this section, we develop hypotheses about how the adoption of an OSS-based business model by software ventures influences the governance of the VC financing that these firms attract. As mentioned above, an OSS-based business model is more complex and difficult to manage than a proprietary software business model. Accordingly, VCs who finance OSS ventures must cope with more severe managerial challenges and greater uncertainty. Consequently, it is reasonable to expect that VC investments in OSS ventures will be more frequently staged than those in their proprietary counterparts. In a similar vein, we contend that OSS ventures will be backed by more syndicates than proprietary software firms and these syndicates will be larger.

Staging and syndication. As mentioned above, staging is the stepwise provision of several rounds of VC finance to entrepreneurial ventures, rather than making an upfront investment of all required capital (Sahlman 1990).

Staging offers two main advantages to VC investors (Gompers 1995, Wang and Zhou 2004). First, it mitigates the agency costs engendered by entrepreneurs' possible opportunistic behaviors, as the VC investor keeps the option to abandon the venture if it fails to meet its milestones. Second, staging creates a real option for the VC investor to stop financing the venture at each financing round. It allows the VC investor to learn about the entrepreneur and the venture's operations over time and to use the information acquired between each round to make better investment decisions (Bergemann and Hege 1998). 
Staging becomes even more valuable under uncertainty, because the extent of agency costs as well as the value of the exit option available to VCs increases with the uncertainty that surrounds the venture (Li 2008). In accordance with this view, Gompers (1995) showed that lower industry ratios of tangible assets to total assets, higher market-to-book ratios, and greater $R \& D$ intensities are associated with more frequent staging. In a similar vein, Tian (2011) found a positive association between the geographical distance between the entrepreneurial venture and the lead VC investor and the likelihood that the VC would stage the investment. Indeed, when geographical distance between the venture and its investor increases, collecting information about the firm becomes more costly, and monitoring becomes less effective because of a lack of relevant information. Therefore, both agency costs and the value of the exit option increase. Tian (2011) also showed that VC investments in younger firms, which lack a track record and whose future prospects are more uncertain, are more likely to be staged.

As explained in the prior section, an OSS-based business model is complex and difficult to manage; the revenue generation mechanisms of these firms--and ultimately their business prospects-are plagued by high uncertainty. Accordingly, the exit option provided by staging is more valuable than in the case of proprietary software ventures. Moreover, uncertainty complicates monitoring and, thus, increases the agency costs associated to entrepreneurs' opportunistic behavior. Consequently, we expect staging of VC investments to be more prevalent in OSS-based ventures than in proprietary ones. Thus, we hypothesize that:

H1: Ceteris paribus, VC-backed OSS firms have more staged investment rounds than VC-backed proprietary software firms.

Syndication occurs when two or more VCs jointly invest in the same entrepreneurial venture. Scholars have provided three main motives for syndication of VC investments, which is a popular practice among $\operatorname{VCs}^{5}$ (Brander et al. 2002, Jaaskelainen 2012). First, syndication allows syndicate members to reduce risk. By joining forces and providing a limited amount of money to each venture, they can share the risk of their investment. This also allows them to diversify their investments, a move which lowers the total risk of their investment portfolio (Bygrave 1987). Second, syndication improves selection of high quality ventures in which to invest, because the quality of target entrepreneurial ventures is evaluated separately and double-checked by each syndicate member 
(Lerner 1994, Casamatta and Haritchabalet 2007). Third, to the extent that syndicate members have heterogeneous skills, specialization, and network linkages, they can provide more effective coaching to entrepreneurial ventures than individual VCs. This helps the ventures to enlarge their resource base and capabilities and improves ways in which the ventures are managed (Tian 2012).

Empirical evidence supports the above arguments. Altintig et al. (2013) found that medical device firms that secured all their VC finance before obtaining FDA approval are more likely to be syndicate-backed when uncertainty about their business prospects is very high. Tian (2012) compared a large sample of entrepreneurial ventures backed by a VC syndicate with those backed by an individual VC investor. He showed that VC syndicates tend to invest in young, early stage firms and in earlier financing rounds, where investments are more risky. Using Canadian data, Brander et al. (2002) showed that syndicated VC investments have greater variability and greater average returns than stand-alone investments. Moreover, empirical studies show that VC syndicates add more value to entrepreneurial ventures than VC investors acting alone. Prior work has established that the positive effect of a diversity of skills in a VC syndicate outweighs the free rider problems (Lerner, 1994; Brander et al., 2002); hence, returns to VC syndication are strongly positive on average (Brander et al. 2002; Cumming and Walz 2010). After controlling for the endogeneity of VC syndicate formation, syndicate-backed entrepreneurial ventures were found to exhibit superior innovative and post-IPO operating performances (Tian 2012). They also exhibit lower underpricing and higher market valuation at IPO, in accordance with the view that syndication also conveys a stronger signal to uninformed external parties about the quality of the focal venture.

Based on the above discussion, it is reasonable to expect that, in comparison with VC-backed proprietary software ventures, VC-backed OSS ventures are more likely to receive financing from a syndicate, and their syndicates are likely to be larger. As mentioned above, investments in OSS ventures are more risky than investments in proprietary software ventures, because of the greater uncertainty inherent in the OSS-based business model. Hence, VCs will be more prone to resort to syndicates when investing in OSS ventures than in proprietary software ventures to reduce the risk associated with this kind of investment. For the same reason, we also expect these syndicates to be larger, because OSS ventures are likely to be more inclined than their proprietary software 
counterparts to accept an offer made by a larger VC syndicate. As the OSS-based business model implies severe managerial challenges, larger syndicates can better cope with them due to their greater and diversified competences. This is beneficial for value creation and may contribute to further improvement of the business model, making it less easily replicable by competitors. In addition, syndication credibly certifies the value of an entrepreneurial venture upon exit (Lerner, 1994), which is particularly important for firms that cannot count on the certification effect of patents, which are observable and easier to value (e.g., Cao et al., 2013). Hence, we posit that:

H2a: Ceteris paribus, VC-backed OSS firms are more likely to be syndicated than VC-backed proprietary software firms.

H2b: Ceteris paribus, VC-backed OSS firms have more syndicated investors than VC-backed proprietary software firms.

\section{DATA AND METHODOLOGY SAMPLE}

To build our sample of firms, we first selected VC-backed software entrepreneurial ventures ${ }^{6}$ included in the VentureXpert module of the SDC Platinum database (now part of ThomsonOne) which met the following criteria: i) they were located in USA, ii) they received their first round of VC investment from 1994-2008, and iii) they were 10 years old or younger at the time of the first VC investment. A total of 4,226 companies met these three criteria.

To identify OSS ventures, we resorted to three different sources. First, following Dahlander (2007), we examined the business descriptions of ventures provided by SDC Platinum. We identified OSS ventures by searching for the words "open source" in the business description. We then labeled the ones that clearly referred to ventures developing open source software as OSS ventures. Fourteen ventures turned out to have unambiguously adopted an OSS-based business model, based on their business descriptions. Second, we added to this group ventures that were identified as OSS ventures in “The 451 group” reports (Aslett 2009, Aslett 2010). Aslett (2009, 2010) provides a list and description of OSS ventures that received VC investments from 1997-2010. Of the 151 ventures mentioned in the reports, we were able to match 53 ventures with the sample extracted from SDC Platinum. Third, in 
accordance with Fosfuri et al. (2008), we extracted all articles about new product announcements from the Gale Group PROMT and ASAP databases ${ }^{7}$ that met the following criteria: i) the article was published from 1994-2012, ii) it referred to the SIC code 7372 (software), and iii) it included one or more of the following words: ["Open source," "OSS," "FLOSS (free libre open source software)," "Linux," "Apache," or "free software."] We extracted approximately 1,500 product announcements. To classify a product announcement as relating to an OSS company, all the extracted announcements were carefully read by a trained research assistant and checked by one of the authors (see examples in Appendix 1 of supplementary appendix). Thus, we were able to select an additional 52 companies. Altogether, we identified 119 OSS ventures ${ }^{8}$. This group includes companies that received scholarly and public attention, such as SugarCRM; Red Hat, Inc.; JasperSoft Corporation; and SpikeSource, Inc.

To build a control group composed of proprietary software entrepreneurial ventures, we considered all software product announcements extracted from the Gale Group PROMT and ASAP databases (considering search criteria i and ii, mentioned above) and searched these documents for the names of the remaining 4,107 ventures from SDC Platinum. To be certain that the selected ventures did not have any OSS products, we manually read the documents and double-checked the description provided by SDC Platinum. In this way, we were able to identify 381 proprietary software entrepreneurial ventures.

Our final sample includes 500 software entrepreneurial ventures, which received 2,018 rounds of VC investment. The rounds of investments were recorded until the end of 2012.

\section{DEPENDENT VARIABLES}

Staging. Staging (H1) is captured by the number of VC rounds (Rounds) received by the focal venture (Tian 2011) ${ }^{9}$.

Syndication. We proxy syndication with two variables. First, we define Syndicated deal (H2a) as a dummy variable, which takes the value 1, if a particular round has more than one VC investing in a venture, and 0 otherwise (Brander et al. 2002). Second, we use Syndication size (H2b), defined as the number of unrelated VC funds that co-invested in the same round (Lerner 1994).

\section{INDEPENDENT VARIABLES}

The key independent variable in the empirical analysis, OSS, is a dummy variable that equals 
1 , if the investee firm is an OSS venture, and 0 otherwise.

\section{CONTROL VARIABLES}

We also control for characteristics of entrepreneurial ventures, investment round, and the general economic environment that could impact our dependent variables.

Characteristics of entrepreneurial ventures. We control for the stage of the lifecycle in which the entrepreneurial venture was at the first round of the investment. Early stage investments are riskier (Gompers and Lerner 2004), because ventures lack a track record and require larger effort to achieve success. Early stage is a dummy variable, which takes a value equal to 1, if the entrepreneurial venture is performing activities related to product development, initial marketing, manufacturing, or sales ${ }^{10}$ at the time of the first round of investment, and 0 otherwise. Moreover, VCs and entrepreneurial ventures tend to cluster in specific regions. In North America, the majority of VC investments are in California and Massachusetts. Hence, we control for geographic location of entrepreneurial ventures by two dummy variables for California and Massachusetts, which indicate whether ventures are located in the respective states. "Other States” is the omitted category. Several studies have shown that patents play a role in attracting VC investment (e.g., Mann and Sager 2007). When information asymmetries are more pronounced, patents matter more as signal of quality (Hsu and Ziedonis 2013). The variable Patent measures the number of patent applications by entrepreneurial ventures in our sample, prior to the year in which they received the VC investment. Considering the application year, instead of the grant year, is more appropriate, as it can take several years from application until a patent is granted, and the application date is closer to the time the venture engaged in the innovative activity (Hsu and Ziedonis 2013). We also control for the subsector of the software industry in which the entrepreneurial venture operated, based on The North American Industry Classification System (NAICS) provided by SDC Platinum. We used three dummy variables, which indicate whether the entrepreneurial venture primary subsector is "Software Publishers," "Software Reproducing,” or “Others” (omitted category).

Characteristics of the deal. At the first round of VC investment, information asymmetry is substantially larger than in subsequent rounds. Indeed, the receipt of the first VC round sends a 
positive signal about the quality of the focal entrepreneurial venture (Li 2008). First round is a dummy variable indicating that the observation relates to the first round of funding. We also control for venture age at the time of the $\mathrm{VC}$ investment (Age), because information asymmetries between entrepreneurs and investors are greater for younger firms without a track record (Sorensen 2007).

Macroeconomic conditions. Finally, we consider several variables that reflect general market and macroeconomic conditions. VC market size is a proxy for the total amount of VC investment in the focal year, and $S \& P$ index controls for public market situation (Cumming et al. 2011). Following Nahata (2008), we resort to two dummy variables to account for the booming information technology market (Bubble) from 1998-2000 and the market crash due to the financial crisis from 2007-2009 (Crisis).

\section{EMPIRICAL METHODOLOGY}

In this study, we focus on the impact of ventures' adoption of an OSS-based business model, compared to a proprietary software business model, on the following attributes of VC investments received by the ventures-the number of VC rounds, the presence of a syndicated deal, and the size of the VC syndicates. In all models, the subscript $n$ refers to the deal number, while the subscript $j$ refers to the ventures. The level of analysis for the hypothesis dealing with staging (H1) is the venture, while the level of analysis for the hypotheses dealing with syndication (H2a and $\mathrm{H} 2 \mathrm{~b}$ ) is the investment round.

Staging and syndication. Our analysis uses the following specification:

$$
\mathrm{Y}_{\mathrm{nj}}=\beta_{1} \cdot \mathrm{OSS}_{\mathrm{j}}+\sum \alpha \cdot \mathrm{DEAL}_{\mathrm{nj}}+\sum \theta \cdot \mathrm{PC}_{\mathrm{j}}+\sum \delta \cdot \mathrm{Y}_{\mathrm{t}}+\varepsilon_{\mathrm{nj}}
$$

Where $Y_{n j}$ equals the number of rounds received by the entrepreneurial venture $j^{11}$, the syndication size, and the syndicated deal, respectively. Since the number of rounds (H1) and syndication size (H2b) are count variables, we use count models for estimation. We estimate our main models using Poisson regressions. We repeated all estimates with negative Binomial models to test the robustness of our results to the choice of the model. The results are similar (reported in supplementary appendix). Syndicated deals (H2a) imply a dummy variable; hence, we use the Probit model. 
$\mathrm{DEAL}_{\mathrm{nj}}$ includes a series of variables, which refer to each round of investments. $\mathrm{PC}_{\mathrm{j}}$ is a vector of variables referring to characteristics of venture $j$, respectively. $\mathrm{Y}_{\mathrm{t}}$ includes macroeconomics variables.

The level of analysis for the number of rounds is the entrepreneurial venture ( $N=500)$; hence, we focus only on the first round characteristics. Including only the first round in the regressions is more appropriate because, after the first round, the characteristics of the venture become endogenous to the round (other specifications, such as averaging round characteristics over time, do not materially affect our main results and are available on request). The level of analysis for the syndication size and the syndicated deal is at the round level $(\mathrm{N}=2,018)$. Because the level of analysis at the round level involves several observations for the same entrepreneurial venture, we cluster standard errors by entrepreneurial ventures.

\section{RESULTS}

\section{DESCRIPTIVE STATISTICS}

$\underline{\text { Table } 1}$ illustrates univariate analysis of differences in the value of the dependent variables between OSS and proprietary software entrepreneurial ventures.

On average, OSS (proprietary software) entrepreneurial ventures received 5.04 (3.7) rounds of VC funding. The null hypotheses that mean and median are equal across the two groups of ventures are rejected at the $1 \%$ level. We can see that $78 \%$ (72\%) of VC financing that OSS (proprietary software) entrepreneurial ventures receive is in syndicated deals. The null hypotheses that the mean and median are equal across the two groups of ventures are rejected at the $1 \%$ level. The mean of syndication size in OSS ventures is 3.24 , and it is slightly larger than the one relating to proprietary software ventures, which is 3.09. The difference between the two means is not statistically significant. Table 2 reports summary statistics and the pairwise correlation of all variables.

\section{[Tables 1, 2 about here]}

\section{STAGING}

To test H1, we use the number of rounds that the VCs invested in the entrepreneurial venture as a dependent variable. Because the number of rounds is measured as the total number of VC investments the venture received, and it is not time variant, we limit the level of analysis to firm level. 
Therefore, the size of the sample is 500 observations. Table 3 illustrates the estimates. As model 1 (Poisson) shows, in accordance with H1, OSS ventures receive a greater number of rounds of VC funding than proprietary software ventures. In model 1, the coefficient of OSS is significant at $1 \%$ and indicates that OSS ventures receive VC funding on average in 1.32 more rounds. Thus, $\mathrm{H} 1$ is supported.

The control variables show that entrepreneurial ventures located in Massachusetts receive a greater number of rounds. The number of rounds is also higher in the software publishing subsector. Additionally, entrepreneurial ventures that receive the first round of VC when they are older have a smaller numbers of rounds.

\section{[Table 3 about here]}

\section{SYNDICATION}

As mentioned above, we use two variables to measure syndication--syndicated deal (H2a) and syndication size (H2b). As we can observe in model 2 (Probit model) of Table 3, the coefficients of OSS are weakly significant $(\mathrm{p}<0.1)$. The marginal effect indicates that OSS ventures are $7 \%$ more likely to receive investment in a syndicated deal. In model 3, there is no significant difference in syndication size between OSS ventures and proprietary ventures ( $\mathrm{p}>0.1$ ). Hence, we find some support for H2a but no support for H2b.

The control variables show that entrepreneurial ventures that receive the first round of VC at an early stage have higher probability to receive a syndicated deal and a larger syndication size. Similar results are observed for ventures located in California. In software publishing and software reproduction subsectors, the probability of receiving a syndicated deal is larger. Our results further indicate that more patent applications are associated with larger syndicates. First round investments have a smaller syndication size and lower probability to be syndicated. An increase in VC market size also increases the size of syndicates and the probability of a syndicated deal. Finally, in a financial crisis, the size of syndication decreases.

\section{ADDRESSING ENDOGENEITY ISSUES}

Because the choice of the business model-either based on OSS or proprietary software-by an 
entrepreneurial venture is not random, endogeneity may be an issue. The second concern is that unobserved heterogeneity may bias our results. In order to deal with these methodological problems, we conduct two additional analyses.

First, it is possible that OSS ventures are higher (lower) quality entrepreneurial ventures. If the (unobserved) quality of OSS ventures is higher (lower) than that of proprietary software ventures, a spurious correlation between the OSS and dependent variables may arise. Therefore, in order to consider robustness of the results to a more homogenous subsample of firms of similar quality, we repeat our analysis on a subsample of ventures that had a successful exit (i.e., exits through mergers and acquisitions and IPOs) ${ }^{12}$. This approach is based on the straightforward fact that high quality ventures achieve successful exits (Bengtson and Hsu 2011). As Table 4 illustrates, the results strongly support H1 and H2a, while they weakly support H2b.

\section{[Table 4 about here]}

Second, we control for endogeneity by using instrumental variables (Table 5). We consider a two-stage model. In the first stage, entrepreneurial ventures choose to adopt an OSS-based business model or a proprietary software business model. As an instrument, we use the intensity of individuals with hacking abilities in the region where the focal venture is located ${ }^{13}$. We measure this variable by dividing the numbers of cyber-crimes in each U.S. state by active work forces in the state ${ }^{14}$. The idea behind this variable is fairly simple: a positive attitude and mentality toward OSS encourages the adoption of an OSS-based business model. The choice of instrument is, therefore, relevant and satisfies the exclusion restriction. To check we do not have a weak instrument, we run the first stage using ordinary least square (OLS). The F-statistics for the first stage is larger than 10 and reduces the concern about weak instruments (Bascle 2008).

\section{[Table 5 about here]}

For the main analysis, because OSS is a dummy variable, we use a Probit model in the first stage (model 1 and 3) and insert the predicted probability in the second stage (STATA command: ivtreatreg (probit-OLS)). In the second stage, we treat dependent variables as continuous and use 
OLS $^{15}$. The models 2, 4, and 5 confirm that OSS ventures are associated with more rounds of financing, a higher probability of a syndicated deal, and a larger syndication size. After we control for endogeneity, both the size and statistical significance of the coefficients of OSS are enhanced. Hence, we can find support for H1, H2a, and H2b.

\section{ADDITIONAL ROBUSTNESS CHECKS}

To check the robustness of our results and rule out alternative explanations, we run several additional analyses. The tables are provided in a supplementary appendix ${ }^{16}$.

First, one might argue that because of the high uncertainty and managerial complexity associated with OSS ventures, they receive funding from investors who are systematically different from those who invest in proprietary software ventures. For example, higher quality VCs are more likely to invest in more uncertain businesses and industries (Petkova et al. 2014) not only because they can add more value but also because they have higher risk tolerance (Tian and Wang 2014). In this case, the differences in staging and syndication may be due to differences in the risk tolerance of VCs. Therefore, we control for VC quality using the IPO experience of the lead investor (Nahata, 2008). IPO experience is measured as the natural logarithm (plus one) of the number of investments in entrepreneurial ventures that eventually went public. Our results regarding the number of rounds (H1) remain unchanged. We do not find any significant relationship between OSS and the dependent variables for syndication (H2a and $\mathrm{H} 2 \mathrm{~b})$.

Second, in our sample, more recent years include more observations belonging to OSS ventures. It is possible that the results we observe are spurious because the OSS phenomenon (and consequently OSS ventures) has gained momentum in recent years. After the initial public offering of VA Linux and Red Hat in 1999, OSS ventures attracted increasing interest from VCs. To capture this change in the environment, we include a dummy variable, which equals 1 if a round of investment takes place after 2000. The results show support for H1 and H2b. Similarly, we repeat the analysis for the subsample of ventures that received a first round of investments after 2000.

Third, we compared OSS and proprietary entrepreneurial ventures. To ensure that the nonrandomness of the sample does not bias our results, we employ propensity score matching to compare OSS ventures with twin ventures that adopt a proprietary software business model. We used the 
nearest neighbor methodology with replacement by considering the two nearest neighbors, based on entrepreneurial venture characteristics (Patents, Venture age, geographical location, and subsectors); deal characteristics (First investment); and macroeconomic factors (VC market size, Bubble, and Financial crisis). The results of analysis on the matched sample confirm that OSS ventures receive funding in more rounds, and investment is more likely to be syndicated, consistent with H1 and H2a. We do not find any support for H2b.

\section{DISCUSSION AND CONCLUSION}

This paper investigates how the adoption of OBMs by entrepreneurial ventures impacts the governance -in terms of staging and syndication- of VC investments that these firms attract. We focus on OSS-based business models as a prominent category of OBMs and compared OSS ventures with firms adopting a proprietary software business model. We argued that the former face greater complexity and uncertainty in their system of activities and revenue generating mechanisms than the latter. Accordingly, we hypothesized that VCs investing in OSS ventures resort more to staging and syndication in order to reduce risk and cope with managerial challenges that complexity generates. Using data on a sample of 500 software entrepreneurial ventures that received VC funding in 2,018 different deals, we found that VC-backed OSS ventures receive funding in more rounds of investment compared to their proprietary counterparts. Likewise, VCs that finance OSS ventures resort more to syndication, even though these syndicates are not significantly larger than those of proprietary software ventures. A possible explanation is that larger syndicates increase coordination costs and lead to delays in decision-making (Gompers and Lerner 2004), two aspects that likely are particularly critical for OSS ventures. Indeed, coordination costs are greater due to the complexity of OSS-based business models relative to that for proprietary software ventures. Moreover, the fact that OSS ventures do not have IPRs exacerbates the importance of time to market for OSS firms and thus makes delays in decision making particularly troublesome.

This study contributes to two important literature streams. First, building on the seminal contribution of Chesbrough (2006), a growing stream of the open innovation research is now focusing on OBMs (Saebi and Foss, 2015). Within this stream, several contributions have highlighted the importance of business models built around the software and knowledge developed by the OSS 
community (see Colombo et al. 2015 for a review). Initially, scholars focused on understanding the main characteristics of OSS-based business models and the motivations behind firms' decision to adopt these business models (Bonaccorsi et al. 2006, Fosfuri et al. 2008, Wen et al. 2013). Several studies examined the strategies that OSS ventures use to collaborate with the OSS community (Dahlander and Magnusson 2005, 2008, O’Mahony and Becky 2008, Colombo et al. 2013). Other contributions examined the impact of OSS-based business models on ventures' performances (Piva et al., 2012; Stam 2009). However, the impact of OSS-based business models on firms' financing has remained under-researched. Alexy and George (2013) represent a notable exception in that they focus on the adoption of OSS-based business models by public firms and explore the impact of this move on their market value. We build upon their work to investigate whether and how the governance of the VC financing that OSS ventures attract differs from that of the VC financing of proprietary software ventures. In so doing, we advance our understanding of how external stakeholders provide resources to firms with OBMs. Second, the paper contributes to the literature investigating the relationship between entrepreneurial ventures’ characteristics and VC investments. Mann and Sager (2007), and Hsu and Ziedonis (2013) studied the role of patents on the evaluation of entrepreneurial ventures, the propensity of receiving VC financing, the terms of financing, and successful exit. Hellmann and Puri (2000) focused on product market strategy and differentiated between innovator entrepreneurial ventures and imitator ones. Hsu (2007) looked at entrepreneurs' experiences, education, and social capital. However, all these empirical studies treat entrepreneurial ventures as homogenous with respect to their business models. We overcome this limitation by contrasting two different business models (open vs. closed) adopted by entrepreneurial ventures and exploring their impact on the governance of the VC financing that ventures receive. Our overarching idea is that different business models entail different degree of complexity (and thus different managing challenges) and riskiness, thus requiring VCs to adapt their governance accordingly.

Venture capital is the most suitable type of financing for privately held, technology-based ventures (Gompers and Lerner 2001). Thus, we are confident that analyzing the effects of OSS-based business models on VC financing is worthwhile. In particular, the relevance of our study is enhanced by the current uptick in companies that build their OBMs around online communities. Nowadays, a 
plethora of firms run electronic marketplaces for ideas (Allio 2004, Dushnitsky and Klueter 2010), auction portals (Amit and Zott 2012), and online travel and booking websites (Filieri 2015). As in the case of OSS ventures, the value generation of these companies crucially depends on the engagement of a community that grows and develops outside their boundaries. There is no contractual bond underlying the strength and persistence of such an engagement; the community self-organizes, and its members act out of idiosyncratic motives and obey unwritten rules. These features complicate the system of activities and revenue generation mechanisms, thus making firms' future prospects highly uncertain. However, these challenges do not seem to deter VCs. OBMs based on online communities are easily scalable and, thus, attractive for VCs. TripAdvisor, the travel website company providing reviews of travel-related content and travel forums is a case in point. The content on these sites is freely accessible for users, who also provide most of it, while the company profits from an advertising business model. Namely, it sells advertising space on its website, which attracts visitors from all around the world, due to the availability of reviews, photos, and maps by millions of travelers. However, managing the travelers' communities is challenging and has frequently caused controversies $^{17}$. Nevertheless, the company has grown steadily since its inception in 2000, made many acquisitions, and attracted $\$ 4$ million of VC funds ${ }^{18}$ before it was acquired by InterActiveCorp in 2004.

As with any other study, this paper has inherent limitations that open avenues for future research. First, two main boundaries limit the generalizability of our results. We focused on software firms that sought and obtained VC finance. Therefore, our results hold true only for VC-backed firms and are not generalizable to the whole population of software entrepreneurial ventures. Studying whether OSS ventures are more or less successful in attracting VC financing might be an interesting addition to our inquiry, despite the challenges of building a reliable control sample. Moreover, we studied OBMs in the software industry only. The widespread diffusion of these business models across many industries calls for an extension of the scope of our analysis.

Second, in this paper, we simply distinguished between OSS ventures and their proprietary counterparts, but the reality may be more nuanced. The literature has recognized the importance of hybrid models (i.e., a mix of OSS and proprietary solutions), which VCs might evaluate as more risky 
and complex, depending how much they deviate from the proprietary business model. We welcome studies on how the extent of this deviation influences the governance of VC investment in OSS ventures. We envisage that this research stream may significantly benefit from the collection of qualitative evidence, which can provide a fine-grained assessment of the business models adopted by entrepreneurial ventures and of their implications for the governance of the VC finance that they receive.

Furthermore, revenue-generating mechanisms vary across OSS ventures. With a larger sample of OSS ventures, one might be able to study the relationship between VC investments and different revenue generating mechanisms. In a similar vein, scholars have documented that OSS ventures apply diverse strategies and organizational arrangements. For instance, Dahlander (2007) showed that OSS ventures can leverage existing OSS projects or initiate new projects, while Colombo et al. (2013) noted that these firms use diverse managerial practices for collaborating with the OSS developers. Future research could distinguish OSS ventures based on their strategies and organization and evaluate whether VCs adapt their governance to it.

Third, in this study, we only focused on the relationship between the business model and the governance of VC financing. However, evidence exists that VC investments have a strong positive effect on various performance measures, such as successful exits (Hsu 2006), total factor productivity, and sales growth (Bertoni et al. 2011). Accordingly, an interesting extension would be to investigate the impact of VC investments on the performance of OSS ventures and proprietary software ventures. Specifically, researchers could examine whether receiving financing from larger VC syndicates and more frequent staging of VC investments has a more positive effect on the performance of OSS ventures than on the performance of proprietary software ventures.

Despite these limitations, this study has interesting implications for both VCs and entrepreneurs who intend to adopt an OBM. Many success stories appear to suggest that OBMs are attractive for investors. However, investors would do well not to forget that these business models are inherently risky and complex. Accordingly, VCs who invest in ventures with OBMs should be ready to adopt risk-reducing governance strategies based on staging and syndication, even though these two governance forms are not immune from coordination and transaction costs. Staging requires 
supervising the achievement of ventures' milestones, while syndication implies coordinating with other investors, who might have different visions about the future of the venture. Entrepreneurs intending to adopt an OBM should consider that their business model choice may affect not only from where they receive financial resources but also the conditions under which these resources are provided. Specifically, more frequent staging is likely to exert more pressure on the venture to achieve milestones. Syndication brings several benefits, but requires tolerating several part owners that have a right to the firm's capital and potential returns. In other words, it is hard to deny that staging and syndication may shape, and sometimes even restrict, the ways in which entrepreneurs manage their businesses, influencing their strategies and the day-to-day management of their businesses.

\section{REFERENCES}

Allio, R. J. (2004), 'CEO interview: the InnoCentive model of open innovation,' Strategy and Leadership, 32(4), 4 - 9.

Alexy, o. and George, g. (2013), 'Category divergence, straddling, and currency: open innovation and the legitimation of illegitimate categories,' Journal of Management Studies, 50(2) 173-203.

Altintig, Z.A., Chiu, H. and Goktan, M.S. (2013), 'How does uncertainty resolution affect VC syndication?’ Financial Management, 42(3), 611-646.

Amit, R. and Zott, C. (2001), 'Value creation in e-business,' Strategic Management Journal, 22(6-7), 493-520.

Amit, R. and Zott, C. (2012), 'Could your company benefit from a new business model? consider these six questions,' MIT Sloan Review, March $20^{\text {th }}$.

Aslett, M. (2010), Open to investment: venture funding for open-source-related vendors. THE 451 GROUP: New York.

Aslett, M. (2009), Open to investment: venture funding for open source 1997-2008. THE 451 GROUP: New York.

Audretsch, D. (1995), Innovation and Industry Evolution, MIT Press, MA: Cambridge.

Bascle, G. (2012), 'Controlling for endogeneity with instrumental variables in strategic management research,’ Strategic Organization, 6(3), 285-327

Barney, J. (1991), 'Firm resources and sustained competitive advantage,' Journal of Management, 17(1), 99-120.

Bengtsson, O. and Hsu, D.H. (2010), 'How do venture capital partners match with startup founders?,' Working Paper edn. http://papers.ssrn.com/sol3/papers.cfm?abstract_id=1568131.

Bergemann, D. and Hege, U. (1998), 'Venture capital financing, moral hazard, and learning,' Journal of Banking and Finance, 22(6-8), 703-735.

Bertoni, F., Colombo, M.G. and Grilli, L. (2013), 'Venture capital investor type and the growth mode of new technology-based firms,' Small Business Economics, 40(3), 527-552.

Bertoni, F., Colombo, M.G. and Grilli, L. (2011), 'Venture capital financing and the growth of hightech start-ups: disentangling treatment from selection effects,' Research Policy, 40(7), 1028-1043.

Bonaccorsi, A., Giannangeli, S. and Rossi, C. (2006), 'Entry strategies under competing standards: hybrid business models in the open source software industry,' Management Science, 52(7), 10851098.

Bonaccorsi, A. and Rossi, C (2006), 'Comparing motivations of individual programmers and firms to take part in the open source movement: from community to business,' Knowledge, Technology and Policy, 18(4), 40-64. 
Brander, J.A., Amit, R. and Antweiler, W. (2002), 'Venture-capital syndication: improved venture selection vs. the value-added hypothesis,' Journal of Economics and Management Strategy, 11(3), 423-452.

Bygrave, W.D. (1987), 'Syndicated investments by venture capital firms - a networking perspective,' Journal of Business Venturing, 2(2), 139-154.

Capra, E., Francalanci, C., Merlo, F. and Rossi-Lamastra, C. (2011), 'Firms' involvement in open source projects: a trade-off between software structural quality and popularity,' Journal of Systems and Software, 84(1), 144-161.

Casadesus-Masanell, R. and Llanes, G. (2011), 'Mixed source,' Management Science, 57(7), 12121230.

Casamatta, C. and Haritchabalet, C. (2007), 'Experience, screening and syndication in venture capital investments,' Journal of Financial Intermediation, 16(3), 368-398.

Cao, J., Jiang, F. and Ritter, J.R. (2013), 'Patent-and innovation-driven performance in venture capitalbacked IPOs,' Available at SSRN 2364668.

Chesbrough, H. W. (2007), 'Why companies should have open business models,' Mit Sloan Management Review, 48(2), 22-27.

Chesbrough, H.W. (2006), Open Business Models: How To Thrive In The New Innovation Landscape. Harvard Business School Press: Boston.

Chesbrough, H.W. (2003), Open Innovation: The New Imperative for Creating and Profiting from Technology. Harvard Business School Press: Boston: MA.

Chesbrough, H.W. and Appleyard, M.M. (2007), 'Open innovation and strategy,' California Management Review, 50(1), 57-76.

Chou, T., Cheng, J. and Chien, C. (2013), 'How useful is venture capital prestige? Evidence from IPO survivability,’ Small Business Economics, 40(4), 843-863.

Colombo, M., Mohammadi A., and Rossi-Lamastra, C. (2014), 'Innovative business models for hightech entrepreneurial ventures: the organizational design challenges,' In N.J. Foss, T. Saebi (eds.), Business Model Innovation: The Organizational Dimension. Oxford University Press: Oxford, UK.

Colombo, M.G., Piva, E. and Rossi-Lamastra, C. (2013), 'Authorising employees to collaborate with communities during working hours: when is it valuable for firms?' Long range planning, 46 (3), 236-257.

Cumming, D. and Dai, N. (2010), 'Local bias in venture capital investments,' Journal of Empirical Finance, 17 (3), 362-380.

Cumming, D., Haslem, B. and Knill, A.M. (2011), 'Entrepreneurial litigation and venture capital finance,' Working Paper edn. http://ssrn.com/abstract=1786479: International Conference of the French Finance Association (AFFI).

Cumming, D., and Walz, U. (2010), 'Private equity returns and disclosure around the world,' Journal of International Business Studies 41(4), 727-754.

Dahlander, L. and Magnusson, M.G. (2005), 'Relationships between open source software companies and communities: observations from Nordic firms,' Research Policy, 34(4), 481-493.

Dahlander, L. (2007), 'Penguin in a new suit: a tale of how de novo entrants emerged to harness free and open source software communities,' Industrial and Corporate Change, 16(5), 913-943.

Dahlander, L. and Magnusson, M. (2008), 'How do firms make use of open source communities?', Long range planning, 41(6), 629-649.

Dahlander, L. and Wallin, M.W. (2006), 'A man on the inside: unlocking communities as complementary assets,' Research Policy, 35(8), 1243-1259.

Dushnitsky, G. and Klueter, T. (2010), 'Is there an eBay for ideas? insights from online knowledge marketplaces,' European Management Review, 8(1), 17-32.

Filieri, R. (2015), 'Why do travelers trust tripadvisor? antecedents of trust towards consumergenerated media and its influence on recommendation adoption and word of mouth,' Tourism Management, 51, 174-185.

Fosfuri, A., Giarratana, M.S. and Luzzi, A. (2008), 'The penguin has entered the building: the commercialization of open source software products,' Organization Science, 19(2), 292-305.

Gandal, N. (1995), 'Competing compatibility standards and network externalities in the pc software market,’ Review of Economics and Statistics, 77(4), 599-608. 
George, G. and Bock, A.J. (2011), 'The business model in practice and its implications for entrepreneurship research,' Entrepreneurship Theory and Practice, 35(1), 83-111.

Goldman, R. and Gabriel, R.P. (2005), Chapter 2 - Innovation Happens Elsewhere. Morgan Kaufmann: San Francisco.

Gompers, P.A. (1995), 'Optimal investment, monitoring, and the staging of venture capital,' The journal of finance, 50(5), 1461-1489.

Gompers, P. and Lerner, J. (2001), 'The venture capital revolution,' The Journal of Economic Perspectives, 15(2), 145-168.

Gompers, P. and Lerner, J. (2004), The Venture Capital Cycle. $2^{\text {nd }}$ ed.. MIT Press: Cambridge.

Gorman, M. and Sahlman, W.A. (1989), 'What do venture capitalists do?,' Journal of Business Venturing, 4(4), 231-248.

Gruber, M. and Henkel, J. (2006), 'New ventures based on open innovation - an empirical analysis of start-up firms in embedded Linux,' International Journal of Technology Management, 33(4), 356372.

Hall, B.H. and Lerner, J. (2012), 'The financing of RandD and innovation,' In B. H. Hall and N. Rosenberg (ed.), Elsevier Handbook of the Economics of Innovation.

Hellmann, T. and Puri, M. (2000), 'The interaction between product market and financing strategy: the role of venture capital,' Review of Financial Studies, 13(4), 959-984.

Henkel, J. (2009),' 'Champions of revealing- the role of open source developers in commercial firms,' Industrial and Corporate Change, 18(3), 435-471.

Hochberg, Y.V., Ljungqvist, A. and Lu, Y. (2007), 'Whom you know matters: venture capital networks and investment performance,' The Journal of Finance, 62(1) 251-301.

Hsu, D. H. (2007), 'Experienced entrepreneurial founders, organizational capital, and venture capital funding,' Research Policy, 36 (5), 722-741

Hsu, D.H. (2006), 'Venture capitalists and cooperative start-up commercialization strategy,' Management Science, 52(2), 204-219.

Hsu, D.H. and Ziedonis, R.H. (2013), 'Resources as dual sources of advantage: implications for valuing entrepreneurial-firm patents,' Strategic Management Journal, 34(7), 761-781.

Jaaskelainen, M. (2012), 'Venture capital syndication: synthesis and future directions,' International Journal of Management Reviews, 14(4), 444-463.

Kaplan, S.N. and Stromberg, P. (2004), 'Characteristics, contracts, and actions: evidence from venture capitalist analyses,’ Journal of Finance, 59(5), 2177-2210.

Katz, M.L. and Shapiro, C., 1985. Network Externalities, Competition, and Compatibility. American Economic Review, 75(3) 424-440.

Lakhani, K.R. and Von Hippel, E. (2003), 'How open source software works: "free" user-to-user assistance,’ Research Policy, 32(6), 923-943.

Laursen, K. and Salter, A. (2006), 'Open for innovation: the role of openness in explaining innovation performance among UK manufacturing firms,' Strategic Management Journal, 27(2), 131-150.

Lerner, J. (1994), 'The syndication of venture capital investments,' Financial Management, 23(3), 1627.

Lerner, J. and Tirole, J., 2002, 'Some simple economics of open source,' Journal of Industrial Economics, 50(2), 197-234.

Li, Y. (2008), 'Duration analysis of venture capital staging: a real options perspective,' Journal of Business Venturing, 23(5), 497-512.

Mann, R.J. and Sager, T.W., 2007. Patents, Venture Capital, and Software Start-Ups. Research Policy, 36(2) 193-208.

Megginson, W.L. and Weiss, K.A. (1991), 'Venture capitalist certification in initial public offerings,' Journal of Finance, 46(3), 879-903.

NAHATA, R. (2008), 'Venture capital reputation and investment performance,' Journal of Financial Economics, 90(2), 127-151.

O'Mahony, S. (2003), 'Guarding the commons: how community managed software projects protect their work,' Research Policy, 32(7), 1179-1198.

O'Mahony, S. and Bechky, B.A. (2008), 'Boundary organizations: enabling collaboration among unexpected allies,' Administrative Science Quarterly, 53(3), 422-459. 
O'Mahony, S. and Ferraro, F. (2007), 'The emergence of governance in an open source community,' Academy of Management Journal, 50(5), 1079-1106.

Perr, J., Appleyard, M.M. and Sullivan, P. (2010), 'Open for business: emerging business models in open source software,' International Journal of Technology Management, 52(3-4), 432-456.

Petkova, A., Wadhwa, A., Yao, X. and Jain, S. (2014), 'Reputation and decision making under ambiguity: a study of u. s. venture capital firms' investments in the emerging clean energy sector,' Academy of Management Journal, 57 (2), 422- 448.

Piva, E., Rentocchini, F. and Rossi-Lamastra, C. (2012), 'Is open source software about innovation? collaborations with the open source community and innovation performance of software entrepreneurial ventures,' Journal of Small Business Management, 50(2), 340-364.

Saebi, T and Foss, N.J. (2015), 'Business models for open innovation: matching heterogeneous open innovation strategies with business model dimensions,' European Management Journal, 33(3), 201213.

Sahlman, W.A. (1990), 'The structure and governance of venture-capital organizations,' Journal of Financial Economics, 27(2), 473-521.

Sandulli, F. D. and Chesbrough, H. (2009), 'The two sides of open business models,' Available at SSRN: http://ssrn.com/abstract $=1325682$.

Sapienza, H. and Timmons, J.A. (1989), 'The roles of venture capitalists in new ventures: what determines their importance?,' Academy of Management Best Paper Proceedings, 74-78.

Shapiro, C. and Varian, H.R. (1998), 'Versioning: the smart way to sell information,' Harvard business review, 76(6), 106-111.

Sorensen, M. (2007), 'How smart is smart money? a two-sided matching model of venture capital,' Journal of Finance, 62(6), 2725-2762.

Spaeth, S., Von Krogh, G. and He, F. (2015), 'Perceived firm attributes and intrinsic motivation in sponsored open source software projects,' Information Systems Research, 26, 224-237.

Stam, W. (2009), 'When does community participation enhance the performance of open source software companies?,' Research Policy, 38 (8), 1288-1299.

Teece, D.J. (1986), 'Profiting from technological innovation - implications for integration, collaboration, licensing and public-policy,’ Research Policy, 15(6), 285-305.

Teece, D.J. (2010), 'Business models, business strategy and innovation,' Long range planning, 43(23), $172-194$.

Tian, X. (2012), 'The role of venture capital syndication in value creation for entrepreneurial firms,' Review of Finance, 16(1), 245-283.

Tian, X. (2011), 'The causes and consequences of venture capital stage financing,' Journal of Financial Economics, 101(1), 132-159.

Tian, X. and Wang, T.Y. (2014), 'Tolerance for failure and corporate innovation,' Review of Financial Studies, 27 (1), 211-255.

Von Krogh, G., Haefliger, S., Spaeth, S. and Wallin, M.W. (2012), 'Carrots and rainbows: motivation and social practice in open source software development,' MIS Quarterly, 36(2), 649-676.

Wang, S.S. and Zhou, H.L. (2004), 'Staged financing in venture capital: moral hazard and risks,' Journal of Corporate Finance, 10(1), 131-155.

Wen, W., Ceccagnoli, M. and Forman, C. (Forthcoming), 'Opening up IP strategy: implications for open source software entry by start-up firms,' Management Science.

West, J. (2007), 'Value capture and value networks in open source vendor strategies,' Proceedings of the Hawai'i International Conference on System Sciences.

Zott, C. and Amit, R. (2007), 'Business model design and the performance of entrepreneurial firms,' Organization Science, 18(2), 181-199.

Zott, C., Amit, R. and Massa, L. (2011), 'The business model: recent developments and future research,' Journal of management, 37(4), 1019-1042. 
TABLES

Table 1-Univariate analysis of number of round, syndication size, and probability of syndicated deal between OSS and proprietary software entrepreneurial ventures

\begin{tabular}{|c|c|c|c|c|}
\hline \multirow{2}{*}{ Variable } & \multirow{2}{*}{$\begin{array}{l}\text { N. of } \\
\text { obs. }\end{array}$} & \multirow{2}{*}{ Mean } & \multicolumn{2}{|c|}{ P-Value of Test of equality } \\
\hline & & & Mean (t-test) & Median (Mann-Whitney \\
\hline \multicolumn{5}{|c|}{ Number of rounds } \\
\hline All PC & 500 & 4.02 & & \\
\hline OSS & 119 & 5.04 & 0.00 & 0.00 \\
\hline Proprietary & 381 & 3.70 & & \\
\hline \multicolumn{5}{|c|}{ Syndication size } \\
\hline All PC & 2,018 & 3.13 & & \\
\hline OSS & 602 & 3.24 & 0.17 & 0.00 \\
\hline Proprietary & 1,416 & 3.09 & & \\
\hline \multicolumn{5}{|c|}{ Syndicated Deal } \\
\hline All PC & 2,018 & 0.73 & & \\
\hline OSS & 602 & 0.78 & 0.00 & 0.00 \\
\hline Proprietary & 1,416 & 0.72 & & \\
\hline
\end{tabular}


Table 2-Summary Statistics and Pairwise correlation matrix $(\mathrm{N}=\mathbf{2 , 0 1 8})$

\begin{tabular}{|c|c|c|c|c|c|c|c|c|c|c|c|c|c|c|c|c|c|}
\hline & Mean & S.D. & $1^{a}$ & 2 & 3 & 4 & 5 & 6 & 7 & 8 & 9 & 10 & 11 & 12 & 13 & 14 & 15 \\
\hline 1-Rounds ${ }^{\mathrm{a}}$ & 4.02 & 2.78 & 1.00 & & & & & & & & & & & & & & \\
\hline 2-Syndication size & 3.14 & 2.34 & 0.01 & 1.00 & & & & & & & & & & & & & \\
\hline 3-Syndicated deal & 0.74 & 0.44 & 0.05 & 0.55 & 1.00 & & & & & & & & & & & & \\
\hline 4-OSS & 0.30 & 0.46 & 0.20 & 0.03 & 0.07 & 1.00 & & & & & & & & & & & \\
\hline 5-Early stage & 0.75 & 0.44 & 0.16 & 0.11 & 0.14 & 0.10 & 1.00 & & & & & & & & & & \\
\hline 6-California & 0.46 & 0.50 & 0.07 & 0.07 & 0.06 & 0.15 & 0.08 & 1.00 & & & & & & & & & \\
\hline 7-Massachussets & 0.17 & 0.37 & 0.13 & 0.01 & 0.05 & -0.01 & 0.08 & -0.41 & 1.00 & & & & & & & & \\
\hline 8-Soft publishing & 0.44 & 0.50 & 0.12 & 0.00 & 0.06 & 0.17 & 0.11 & 0.01 & 0.06 & 1.00 & & & & & & & \\
\hline 9-Soft reproduction & 0.30 & 0.46 & 0.03 & 0.04 & 0.04 & -0.16 & 0.00 & -0.05 & 0.08 & -0.57 & 1.00 & & & & & & \\
\hline 10-Patents & 1.47 & 5.72 & -0.05 & 0.04 & 0.00 & -0.03 & -0.05 & 0.04 & -0.06 & -0.04 & -0.09 & 1.00 & & & & & \\
\hline 11-First investment & 0.25 & 0.43 & & -0.21 & -0.11 & -0.08 & -0.06 & -0.03 & -0.05 & -0.05 & -0.01 & -0.10 & 1.00 & & & & \\
\hline 12-Company age & 4.10 & 3.25 & -0.18 & -0.02 & -0.07 & 0.03 & -0.17 & -0.06 & 0.05 & 0.06 & -0.03 & 0.20 & -0.38 & 1.00 & & & \\
\hline 13-VC market size & 10.09 & 0.39 & -0.12 & 0.11 & 0.05 & 0.05 & 0.00 & -0.01 & -0.01 & 0.14 & -0.23 & 0.05 & -0.14 & 0.14 & 1.00 & & \\
\hline 14-S and $P$ index & 0.13 & 0.20 & 0.12 & 0.06 & 0.02 & -0.23 & 0.00 & -0.01 & 0.10 & -0.19 & 0.25 & -0.02 & -0.05 & -0.07 & -0.22 & 1.00 & \\
\hline 15-Bubble & 0.22 & 0.42 & -0.10 & 0.09 & 0.00 & -0.18 & -0.05 & -0.04 & -0.04 & -0.11 & 0.05 & -0.02 & 0.10 & -0.17 & 0.58 & 0.13 & 1.00 \\
\hline 16-Crisis & 0.24 & 0.43 & -0.03 & -0.05 & -0.02 & 0.27 & 0.08 & 0.09 & -0.04 & 0.22 & -0.25 & 0.12 & -0.21 & 0.35 & 0.09 & -0.33 & -0.30 \\
\hline
\end{tabular}

a. The level of analysis is at entrepreneurial venture level $(\mathrm{N}=500)$ 
Table 3-VC staging and syndication

\begin{tabular}{|c|c|c|c|}
\hline & $\begin{array}{c}\text { (1) } \\
\text { Rounds }\end{array}$ & $\begin{array}{c}\text { (2) } \\
\text { Syndicated deal } \\
\end{array}$ & $\begin{array}{c}\text { (3) } \\
\text { Syndication size } \\
\end{array}$ \\
\hline OSS & $\begin{array}{l}0.279^{* * *} \\
(0.067)\end{array}$ & $\begin{array}{c}0.164^{*} \\
(0.092)\end{array}$ & $\begin{array}{c}0.061 \\
(0.054)\end{array}$ \\
\hline Early stage & $\begin{array}{c}0.083 \\
(0.076)\end{array}$ & $\begin{array}{l}0.263^{* * *} \\
(0.089)\end{array}$ & $\begin{array}{l}0.136^{* *} \\
(0.053)\end{array}$ \\
\hline California & $\begin{array}{c}0.100 \\
(0.069)\end{array}$ & $\begin{array}{l}0.176^{* *} \\
(0.089)\end{array}$ & $\begin{array}{c}0.095^{*} \\
(0.056)\end{array}$ \\
\hline Massachusetts & $\begin{array}{l}0.229^{* * *} \\
(0.088)\end{array}$ & $\begin{array}{c}0.201^{*} \\
(0.119)\end{array}$ & $\begin{array}{c}0.041 \\
(0.068)\end{array}$ \\
\hline Soft publishing & $\begin{array}{l}0.235^{* * *} \\
(0.073)\end{array}$ & $\begin{array}{l}0.255^{* * *} \\
(0.084)\end{array}$ & $\begin{array}{c}0.040 \\
(0.060)\end{array}$ \\
\hline Soft reproduction & $\begin{array}{c}0.122 \\
(0.084)\end{array}$ & $\begin{array}{l}0.307^{* * *} \\
(0.110)\end{array}$ & $\begin{array}{c}0.091 \\
(0.062)\end{array}$ \\
\hline Patents & $\begin{array}{l}-0.008 \\
(0.016)\end{array}$ & $\begin{array}{c}0.007 \\
(0.005)\end{array}$ & $\begin{array}{l}0.006^{* * *} \\
(0.002)\end{array}$ \\
\hline First investment & & $\begin{array}{l}-0.402^{* * *} \\
(0.083)\end{array}$ & $\begin{array}{l}-0.445^{* * *} \\
(0.036)\end{array}$ \\
\hline Company age & $\begin{array}{l}-0.036^{* *} \\
(0.018)\end{array}$ & $\begin{array}{l}-0.048^{* * *} \\
(0.014)\end{array}$ & $\begin{array}{l}-0.020^{* *} \\
(0.008)\end{array}$ \\
\hline VC market size & $\begin{array}{l}-0.095 \\
(0.113)\end{array}$ & $\begin{array}{l}0.321^{* *} \\
(0.147)\end{array}$ & $\begin{array}{l}0.190^{* *} \\
(0.075)\end{array}$ \\
\hline$S$ and $P$ index & $\begin{array}{c}0.295 \\
(0.217)\end{array}$ & $\begin{array}{c}0.176 \\
(0.248)\end{array}$ & $\begin{array}{c}0.126 \\
(0.122)\end{array}$ \\
\hline Bubble & $\begin{array}{l}-0.006 \\
(0.098)\end{array}$ & $\begin{array}{l}-0.169 \\
(0.127)\end{array}$ & $\begin{array}{c}0.047 \\
(0.064)\end{array}$ \\
\hline Crisis & $\begin{array}{l}-0.064 \\
(0.111)\end{array}$ & $\begin{array}{l}-0.162 \\
(0.103)\end{array}$ & $\begin{array}{l}-0.124^{*} \\
(0.064)\end{array}$ \\
\hline Constant & $\begin{array}{c}2.033^{*} \\
(1.135) \\
\end{array}$ & $\begin{array}{l}-2.801^{*} \\
(1.471) \\
\end{array}$ & $\begin{array}{l}-0.828 \\
(0.744) \\
\end{array}$ \\
\hline $\begin{array}{l}\text { N } \\
\text { Chi-square }\end{array}$ & $\begin{array}{c}500 \\
84.629^{* * * *}\end{array}$ & $\begin{array}{c}2,018 \\
98.434^{* * * *}\end{array}$ & $\begin{array}{c}2,018 \\
241.659^{* * *}\end{array}$ \\
\hline
\end{tabular}

Note: In all models, clustered Robust Std. Err. is reported in parentheses; ${ }^{* * *}$ or ${ }^{* * *}$ indicate statistical significance at the $10 \%, 5 \%, 1 \%$ level, respectively. 
Table 4-Repeating all analysis for firms that experience successful exit

(1) (3) (2)

Rounds Syndicated deal Syndication size

\begin{tabular}{|c|c|c|c|}
\hline OSS & $\begin{array}{c}0.260^{* * *} \\
(0.086)\end{array}$ & $\begin{array}{c}0.337^{* *} \\
(0.135)\end{array}$ & $\begin{array}{c}0.128^{*} \\
(0.071)\end{array}$ \\
\hline Early stage & $\begin{array}{l}-0.084 \\
(0.099)\end{array}$ & $\begin{array}{l}0.384^{* * *} \\
(0.112)\end{array}$ & $\begin{array}{l}0.233^{* * *} \\
(0.070)\end{array}$ \\
\hline California & $\begin{array}{c}0.151^{*} \\
(0.089)\end{array}$ & $\begin{array}{c}0.033 \\
(0.104)\end{array}$ & $\begin{array}{l}-0.002 \\
(0.066)\end{array}$ \\
\hline Massachusetts & $\begin{array}{c}0.284^{* *} \\
(0.111)\end{array}$ & $\begin{array}{c}0.080 \\
(0.144)\end{array}$ & $\begin{array}{l}-0.020 \\
(0.080)\end{array}$ \\
\hline Soft publishing & $\begin{array}{c}0.159 \\
(0.098)\end{array}$ & $\begin{array}{l}0.236^{* *} \\
(0.113)\end{array}$ & $\begin{array}{c}0.012 \\
(0.088)\end{array}$ \\
\hline Soft reproduction & $\begin{array}{c}0.014 \\
(0.109)\end{array}$ & $\begin{array}{l}0.362^{* * *} \\
(0.133)\end{array}$ & $\begin{array}{c}0.109 \\
(0.078)\end{array}$ \\
\hline Patents & $\begin{array}{l}-0.072 \\
(0.050)\end{array}$ & $\begin{array}{l}-0.003 \\
(0.008)\end{array}$ & $\begin{array}{c}0.003 \\
(0.005)\end{array}$ \\
\hline First investment & & $\begin{array}{l}-0.424^{* * *} \\
(0.103)\end{array}$ & $\begin{array}{l}-0.430^{* * *} \\
(0.047)\end{array}$ \\
\hline Company age & $\begin{array}{l}-0.023 \\
(0.022)\end{array}$ & $\begin{array}{l}-0.016 \\
(0.018)\end{array}$ & $\begin{array}{l}-0.006 \\
(0.009)\end{array}$ \\
\hline VC market size & $\begin{array}{l}-0.132 \\
(0.119)\end{array}$ & $\begin{array}{c}0.045 \\
(0.168)\end{array}$ & $\begin{array}{c}0.118 \\
(0.087)\end{array}$ \\
\hline$S$ and $P$ index & $\begin{array}{c}0.469^{*} \\
(0.244)\end{array}$ & $\begin{array}{l}-0.075 \\
(0.304)\end{array}$ & $\begin{array}{c}0.090 \\
(0.174)\end{array}$ \\
\hline Bubble & $\begin{array}{c}0.067 \\
(0.123)\end{array}$ & $\begin{array}{c}0.071 \\
(0.168)\end{array}$ & $\begin{array}{c}0.083 \\
(0.082)\end{array}$ \\
\hline Fin crisis & $\begin{array}{l}-0.456^{* *} \\
(0.190)\end{array}$ & $\begin{array}{l}-0.296^{*} \\
(0.171)\end{array}$ & $\begin{array}{l}-0.228^{* * *} \\
(0.080)\end{array}$ \\
\hline Constant & $\begin{array}{c}2.478^{* *} \\
(1.186) \\
\end{array}$ & $\begin{array}{l}-0.151 \\
(1.671) \\
\end{array}$ & $\begin{array}{l}-0.143 \\
(0.875) \\
\end{array}$ \\
\hline $\begin{array}{l}\text { N } \\
\text { Chi-square }\end{array}$ & $\begin{array}{c}293 \\
63.450^{* * *}\end{array}$ & $\begin{array}{c}1151 \\
73.509^{* * *}\end{array}$ & $\begin{array}{c}1151 \\
149.266^{* * *}\end{array}$ \\
\hline
\end{tabular}


Table 5-Endogeneity check by using instrumental variables (IV)

\begin{tabular}{|c|c|c|c|c|c|}
\hline & $\begin{array}{c}\text { (1) } \\
\text { OSS }\end{array}$ & $\begin{array}{c}\text { (2) } \\
\text { Rounds }\end{array}$ & $\begin{array}{c}\text { (3) } \\
\text { OSS }\end{array}$ & $\begin{array}{c}\text { (4) } \\
\text { Syndicated deal }\end{array}$ & $\begin{array}{c}\text { (5) } \\
\text { Syndication size }\end{array}$ \\
\hline OSS predicted & & $\begin{array}{l}7.368^{* * *} \\
(1.933)\end{array}$ & & $\begin{array}{l}0.418^{* *} \\
(0.177)\end{array}$ & $\begin{array}{l}1.831^{* *} \\
(0.912)\end{array}$ \\
\hline Hacker intensity & $\begin{array}{l}0.032^{* *} \\
(0.013)\end{array}$ & & $\begin{array}{l}0.035^{* * *} \\
(0.006)\end{array}$ & & \\
\hline Early stage & $\begin{array}{c}0.201 \\
(0.161)\end{array}$ & $\begin{array}{c}0.003 \\
(0.302)\end{array}$ & $\begin{array}{l}0.228^{* * *} \\
(0.077)\end{array}$ & $\begin{array}{l}0.081^{* * *} \\
(0.028)\end{array}$ & $\begin{array}{l}0.322^{* *} \\
(0.134)\end{array}$ \\
\hline Soft publishing & $\begin{array}{c}0.208 \\
(0.153)\end{array}$ & $\begin{array}{l}0.544^{*} \\
(0.322)\end{array}$ & $\begin{array}{l}0.182^{* *} \\
(0.079)\end{array}$ & $\begin{array}{l}0.069^{* *} \\
(0.027)\end{array}$ & $\begin{array}{c}0.004 \\
(0.142)\end{array}$ \\
\hline Soft reproduction & $\begin{array}{l}-0.191 \\
(0.181)\end{array}$ & $\begin{array}{l}0.720^{* *} \\
(0.313)\end{array}$ & $\begin{array}{l}-0.180^{* *} \\
(0.089)\end{array}$ & $\begin{array}{l}0.134^{* * *} \\
(0.029)\end{array}$ & $\begin{array}{l}0.423^{* * *} \\
(0.148)\end{array}$ \\
\hline Patents & $\begin{array}{l}-0.109 \\
(0.071)\end{array}$ & $\begin{array}{c}0.015 \\
(0.024)\end{array}$ & $\begin{array}{l}-0.020^{* * *} \\
(0.006)\end{array}$ & $\begin{array}{l}0.004^{*} \\
(0.002)\end{array}$ & $\begin{array}{l}0.029^{* *} \\
(0.014)\end{array}$ \\
\hline First investment & & & $\begin{array}{l}-0.183^{* *} \\
(0.082)\end{array}$ & $\begin{array}{l}-0.121^{* * *} \\
(0.028)\end{array}$ & $\begin{array}{l}-1.178^{* * *} \\
(0.124)\end{array}$ \\
\hline Company age & $\begin{array}{l}-0.050 \\
(0.035)\end{array}$ & $\begin{array}{l}-0.028 \\
(0.067)\end{array}$ & $\begin{array}{l}-0.012 \\
(0.011)\end{array}$ & $\begin{array}{l}-0.012^{* * *} \\
(0.004)\end{array}$ & $\begin{array}{l}-0.056^{* * *} \\
(0.019)\end{array}$ \\
\hline VC market size & $\begin{array}{c}0.134 \\
(0.162)\end{array}$ & $\begin{array}{l}-0.346 \\
(0.295)\end{array}$ & $\begin{array}{l}-0.081 \\
(0.085)\end{array}$ & $\begin{array}{l}0.063^{* *} \\
(0.027)\end{array}$ & $\begin{array}{l}0.722^{* * *} \\
(0.150)\end{array}$ \\
\hline$S$ and $P$ index & $\begin{array}{l}-0.533 \\
(0.432)\end{array}$ & $\begin{array}{l}2.677^{* * *} \\
(0.833)\end{array}$ & $\begin{array}{l}-1.215^{* * *} \\
(0.176)\end{array}$ & $\begin{array}{c}0.142 \\
(0.087)\end{array}$ & $\begin{array}{l}1.037^{* *} \\
(0.411)\end{array}$ \\
\hline Crisis & $\begin{array}{c}0.538^{* *} \\
(0.239)\end{array}$ & $\begin{array}{l}-1.481^{* *} \\
(0.641)\end{array}$ & $\begin{array}{l}0.518^{* * *} \\
(0.082)\end{array}$ & $\begin{array}{l}-0.124^{* * *} \\
(0.045)\end{array}$ & $\begin{array}{l}-0.760^{* * *} \\
(0.242)\end{array}$ \\
\hline Region Human Capital & $\begin{array}{c}1.188^{* *} \\
(0.523)\end{array}$ & & $\begin{array}{l}1.195^{* * *} \\
(0.254)\end{array}$ & & \\
\hline Constant & $\begin{array}{l}-3.840^{* *} \\
(1.838)\end{array}$ & $\begin{array}{c}5.159^{*} \\
(3.030)\end{array}$ & $\begin{array}{l}-1.707^{*} \\
(0.944)\end{array}$ & $\begin{array}{l}-0.062 \\
(0.294)\end{array}$ & $\begin{array}{l}-4.515^{* * *} \\
(1.588)\end{array}$ \\
\hline $\mathbf{N}$ & 500 & 500 & 2,018 & 2,018 & 2,018 \\
\hline
\end{tabular}

Note: In all models Robust Std. Err. is reported in parentheses; ${ }^{* * *}$ or ${ }^{* * *}$ indicate statistical significance at the $10 \%, 5 \%, 1 \%$ level, respectively. 


\section{ENDNOTES}

${ }^{1}$ In this paper, we define a business model as the way a firm operates to "create and deliver value to customers" (Teece 2010: 173).

${ }^{2}$ We thank an anonymous referee for highlighting this important and straightforward point.

${ }^{3}$ Sometimes, firms create from scratch OSS projects to develop specific solutions (i.e., sponsored OSS projects (Spaeth et al., 2015)).

${ }^{4}$ OSS ventures can also use available codes developed by an OSS project without any significant contribution to the project. Dahlander and Magnusson (2005) refer to this approach as parasitic and argue that it may create a negative image in the community and even lead to conflicts with the community, which may perceive the venture as a free rider.

${ }^{5}$ From 1980-2005, about 70\% of the 30,861 entrepreneurial ventures considered by Tian (2012) were syndicate-backed. Data from a database relating to 1,663 VC investments in entrepreneurial ventures located in seven European countries reveal that $65.7 \%$ of these investments were syndicated (see Bertoni et al. 2013).

${ }^{6}$ Our sample does not include entrepreneurial ventures that did not receive VC. Indeed, we do not study whether OSS ventures are more or less likely to attract VC investments than their proprietary software counterparts. Rather, we focus our analysis on the syndication and staging of the VC investments, conditional on having obtained VC.

${ }^{7}$ In order to detect whether an article was about a new product announcement, we checked whether the following words were included in the article: "product announcement," "product introduction," "product/service review," and "software evaluation."

${ }^{8}$ This sample is larger than those used by prior studies that focused on OSS ventures. For instance, Wen et al. (2013) identified 85 OSS ventures, and Dahlander (2007) identified 67 OSS ventures.

${ }^{9}$ Gompers and Lerner (1999) argue that the SDC database overstated the rounds of financing and considers any separate investment dates as a new round. For robustness, we consider the investment rounds that happen in time intervals shorter than 90 days as one round. The results are qualitatively similar and are available upon request.

${ }^{10}$ This variable is based on the definition provided by SDC Platinum.

${ }^{11}$ Because the level of analysis for the number of rounds is the entrepreneurial venture, the variable $Y_{n j}$ becomes $Y_{j}$. The same holds for DEAL $L_{n j}$ and $\varepsilon_{n j}$.

${ }^{12}$ We thank an anonymous referee for highlighting this important point.

${ }^{13}$ In order to separate this effect from human capital, in the first stage we control for the number of highly skilled individuals by calculating the number of $\mathrm{PhD}$ graduates in computer science relative to the number of active work forces.

${ }^{14}$ These data come from http://www.fbi.gov/about-us/investigate/cyber.

${ }^{15}$ Alternatively, we use the Heckman treatment (STATA command: ivtreatreg (heckit)) and the full information maximum likelihood (FIML) endogenous switching Poisson model (STATA command: espoisson). The results in both cases are similar to our preferred model.

${ }^{16}$ We also performed several additional analyses in a supplementary appendix, which, due to brevity, are not discussed in this paper.

$17 \quad$ For instance, in March 2014, the TripAdvisor's Chinese site came under scrutiny because a Chinese research firm uncovered that a reviewer had reviewed 51 Parisian restaurants in one month, while also reviewing 50 hotels in other countries.

${ }_{18} \mathrm{http}: / /$ bostonvcblog.typepad.com/vc/2012/08/tripadvisor-is-to-travel-reviews-what-kleenex-is-totissues-henry-harteveldt-forrester-tripadvisor-may-be-o.html, accessed on August $1^{\text {st }} 2014$. 